\title{
Twentieth-century warming preserved in a Geladaindong mountain ice core, central Tibetan Plateau
}

\author{
Yulan ZHANG, ${ }^{1,4}$ Shichang KANG, ${ }^{1,2}$ Bjorn GRIGHOLM, ${ }^{5}$ Yongjun ZHANG, ${ }^{3}$ \\ Susan KASPARI, ${ }^{6}$ Uwe MORGENSTERN, ${ }^{7}$ Jiawen REN, ${ }^{1}$ Dahe QIN, ${ }^{1}$ \\ Paul A. MAYEWSKI, ${ }^{5}$ Qianggong ZHANG, ${ }^{2,3}$ Zhiyuan CONG, ${ }^{2,3}$ \\ Mika SILLANPÄ̈̈̈, ${ }^{4}$ Margit SCHWIKOWSKI, ${ }^{8}$ Feng $\mathrm{CHEN}^{3}$ \\ ${ }^{1}$ State Key Laboratory of Cryospheric Sciences, Cold and Arid Regions Environmental and Engineering Research Institute, \\ Chinese Academy of Sciences, Lanzhou, China \\ ${ }^{2}$ CAS Center for Excellence in Tibetan Plateau Earth Sciences, Chinese Academy of Sciences, Beijing, China \\ ${ }^{3}$ Key Laboratory of Tibetan Environment Changes and Surface Processes, Institute of Tibetan Plateau Research, \\ Chinese Academy of Sciences, Beijing, China \\ ${ }^{4}$ Laboratory of Green Chemistry, Lappeenranta University of Technology, Mikkeli, Finland \\ ${ }^{5}$ Climate Change Institute and Department of Earth Sciences, University of Maine, Orono, ME, USA \\ ${ }^{6}$ Department of Geological Sciences, Central Washington University, Ellensburg, WA, USA \\ ${ }^{7}$ Institute of Geological and Nuclear Sciences, National Isotope Centre, Lower Hutt, New Zealand \\ ${ }^{8}$ Laboratory of Radiochemistry and Environmental Chemistry, Paul Scherrer Institut, Villigen PSI, Switzerland \\ Correspondence: Shichang Kang <shichang.kang@/zb.ac.cn>
}

\begin{abstract}
High-resolution $\delta^{\mathbf{1 8}} \mathrm{O}$ records from a Geladaindong mountain ice core spanning the period 1477-1982 were used to investigate past temperature variations in the Yangtze River source region of the central Tibetan Plateau (TP). Annual ice-core $\delta^{18} \mathrm{O}$ records were positively correlated with temperature data from nearby meteorological stations, suggesting that the $\delta^{18} \mathrm{O}$ record represented the air temperature in the region. A generally increasing temperature trend over the past 500 years was identified, with amplified warming during the 20th century. A colder stage, spanning before the 1850s, was found to represent the Little Ice Age with colder periods occurring during the 1470s-1500s, 1580s1660s, 1700s-20s and 1770s-1840s. Compared with other temperature records from the TP and the Northern Hemisphere, the Geladaindong ice-core record suggested that the regional climate of the central TP experienced a stronger warming trend during the 20th century than other regions. In addition, a positive relationship between the Geladaindong $\delta^{18} \mathrm{O}$ values and the North Atlantic Oscillation index, combined with a wavelet analysis of $\delta^{18} \mathrm{O}$ records, indicated that there was a potential atmospheric teleconnection between the North Atlantic and the central TP.
\end{abstract}

KEYWORDS: climate change, ice chronology/dating, ice core

\section{INTRODUCTION}

The Tibetan Plateau (TP) contains 36793 glaciers covering $49873 \mathrm{~km}^{2}$, the largest glacier extent outside the polar regions (Shi, 2008). It is often referred to as the 'Asian water tower' since it is the source region of many major Asian rivers (Immerzeel and others, 2010). Remote-sensing data and in situ observations over the TP have revealed that glacier retreat is widespread (Pu and others, 2008; Yao and others, 2012). These glaciers act as natural archives, preserving detailed information on past environmental and climatic conditions (Thompson and others, 2006a; Yao and others, 2007; Xu and others, 2009; Kang and others, 2010). Ice-core records spanning decades to millennia have indicated that 20th-century warming was a widespread occurrence on the TP (Thompson and others, 2000; Davis and others, 2005; Yao and others, 2007) and has led to dramatic glacial melting (Yao and others, 2012). Millennialscale ice cores have been drilled in the Himalaya (e.g. Dasuopu and East Rongbuk), the Puruogangri ice cap, the Qilian mountains (Dunde) and the Kunlun mountains (Guliya) (Davis and others, 2005; Thompson and others, 2006a; Yao and others, 2007), while few have been drilled in the central TP (Kang and others, 2007; Joswiak and others, 2010). The results of the ice-core analyses have revealed the complexity of the climate over different areas of the TP and indicated that the entire TP was highly sensitive to 20th-century warming (Thompson and others, 2006b; Yao and others, 2007).

Climatically, the TP is dominated by the Indian monsoon during summer and the westerlies during winter and spring (Yanai and $\mathrm{Wu}, 2005$ ). Influenced by intense precipitation occurring when moisture crosses the Himalaya, summer $\delta^{18} \mathrm{O}$ values in precipitation on the southern Tanggula mountains are generally more depleted (amount effect) than those in winter (e.g. Tian and others, 2007; Yao and others, 2013). Additionally, a slight decrease in $\delta^{18} \mathrm{O}$ values in monsoon precipitation between July and September has been observed at Tuotuohe $\left(34^{\circ} 13^{\prime} \mathrm{N}, 92^{\circ} 26^{\prime} \mathrm{E} ; 4533 \mathrm{~m}\right.$ a.s.l.) on the northern slope of the Tanggula mountains (Tian and others, $2001 a, b)$, relative to those observed in the southern Tanggula mountains (Yao and others, 2013). Snow-pit $\delta^{18} \mathrm{O}$ records in this region also display seasonality, with more depleted values occurring during the summer monsoon season (Zhang and others, 2007). This seasonality represents a key information source for ice-core dating. Although seasonal $\delta^{18} \mathrm{O}$ variability generally reflects monsoon precipitation on 


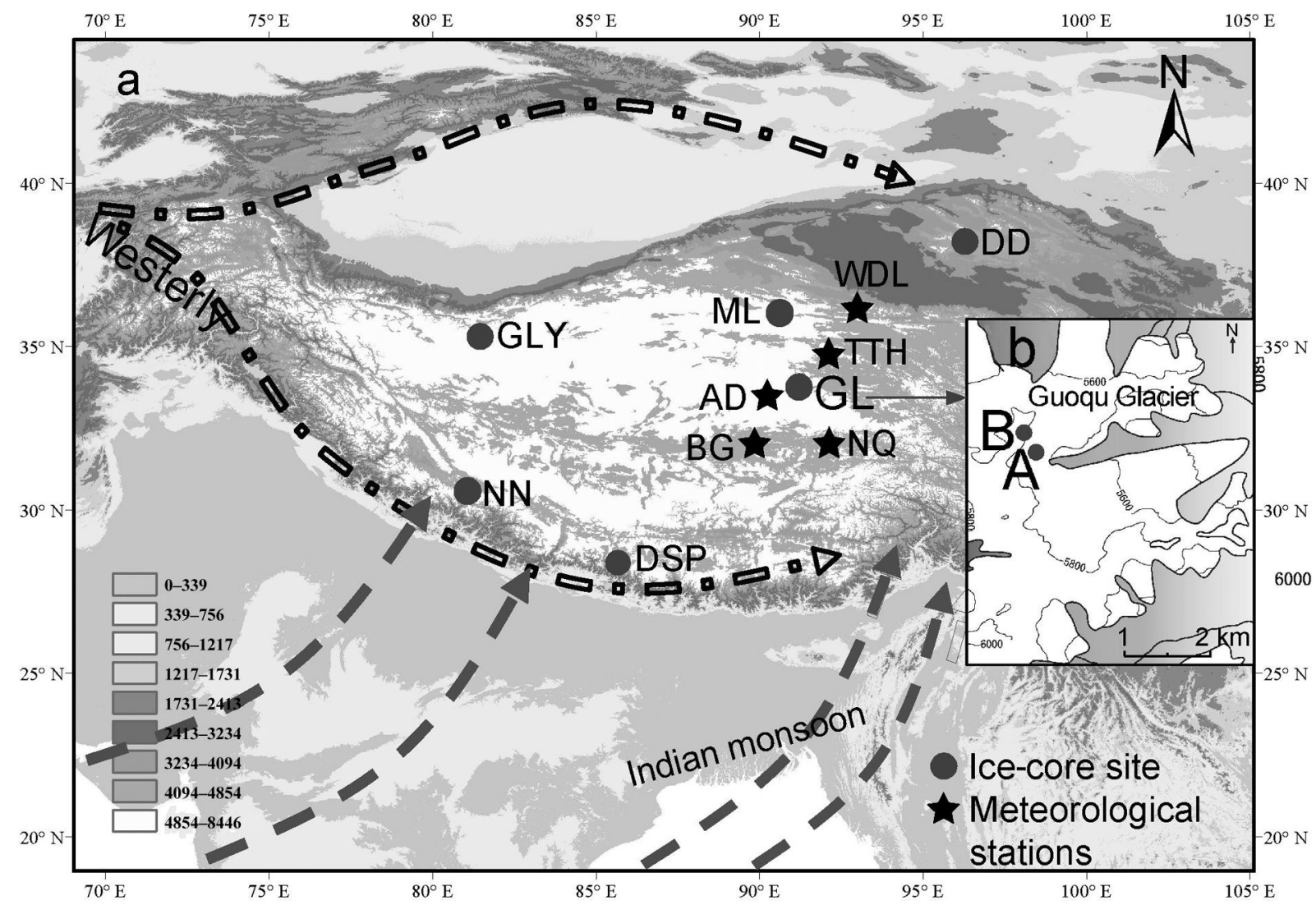

Fig. 1. (a) Location map of the ice-core drilling sites on the Tibetan Plateau (GL: Geladaindong; GLY: Guliya; DD: Dunde; ML: Malan; NN: Naimona'nyi; DSP: Dasuopu) and meteorological stations (WDL: Wudaoliang (35.22 ${ }^{\circ}$ N, $93.08^{\circ} \mathrm{E} ; 4512$ m a.s.l.; 1957-2011); TTH: Tuotuohe

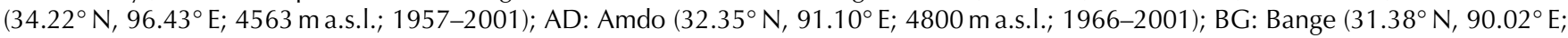
4700 m a.s.l.; $1957-2001)$; NQ: Naqu (31.48 N, 92.07 $\mathrm{E} ; 4507 \mathrm{~m}$ a.s.I.; 1955-2001)) mentioned in this study. (b) Location of the drilling site of Geladaindong ice core in the Geladaindong mountain region (Core A studied by Kang and others, 2007; Core B is our studied core).

the TP, long-term (decadal-millennial) $\delta^{18} \mathrm{O}$ records can be used to reconstruct temperature variations (Thompson and others, 2006b). Ice-core records from the TP have shown agreement on multi-decadal timescales verified by the synchronous cold and warm periods (Yao and others, 2007).

Although the Tanggula mountains contain many glaciers (Shi, 2008), previous studies have focused only on shallow ice-core records of the past several decades (Kang and others, 2007; Joswiak and others, 2010); deep ice-core records from the past hundreds of years or millennium are lacking. This study investigates the climatological significance of $\delta^{18} \mathrm{O}$ records over the past 500 years using a $147 \mathrm{~m}$ deep ice core retrieved from Geladaindong mountain in the Tanggula mountains. Temperature variations in the central TP during the Little Ice Age (LIA) and 20th-century warming are discussed, as well as possible connections with atmospheric circulation in the Northern Hemisphere.

\section{METHODOLOGY}

\subsection{Study area}

The Tanggula mountains, located in the central TP, span from Dorsoidong Co region in the west to the Yushu and Qamdo region (near Hengduan mountain) in the east, with a length $\sim 500 \mathrm{~km}\left(\sim 32-33^{\circ} \mathrm{N}, \sim 90-97^{\circ} \mathrm{E}\right)$ ( $\mathrm{Li}$ and others, 1986). The annual temperature is approximately $-4.4^{\circ} \mathrm{C}$ (from Tuotuohe station). Geladaindong mountain is the highest of the Tanggula mountains with an elevation of 6621 m a.s.l. (Li and others, 1986) (Fig. 1). The Geladaindong mountain region is highly glaciated: 74 glaciers cover an area of $384.1 \mathrm{~km}^{2}$ in the northern part of the mountain (Shi, 2008) and 29 glaciers cover $182.1 \mathrm{~km}^{2}$ in the southern part. Yao and others (2012) have reported a decreasing trend in glacier mass balance in the interior of the TP. Glacier areas decreased by $4.7 \mathrm{~km}^{2}$ from 1969 to $1976,15.4 \mathrm{~km}^{2}$ from 1976 to 1992 , and $22.4 \mathrm{~km}^{2}$ from 1992 to 2002 in the Geladaindong region, suggesting accelerated glacier retreat in recent years (Ye and others, 2006).

\subsection{Ice coring and sampling}

During the Sino-US Cooperation Expedition on Geladaindong mountain in November 2005, a $147 \mathrm{~m}$ ice core (Core B) was collected from the upper basin of Guoqu glacier $\left(33.58^{\circ} \mathrm{N}, 91.18^{\circ} \mathrm{E} ; 5750 \mathrm{~m}\right.$ a.s.l.) on the northern slope of the mountain using an electromechanical drill (Fig. 1). Before the ice-core drilling, a $0.78 \mathrm{~m}$ deep snow pit was excavated to the glacial ice, representative of 1 year's conversion of snow to ice at the site. The ice core was packed in polyethylene tubing in the field, transported frozen to the State Key Laboratory of Cryospheric Sciences (SKLCS), Chinese Academy of Sciences, Lanzhou, and kept in a cold room at $-20^{\circ} \mathrm{C}$ until sample preparation. The snow pit was sampled with a resolution of $50 \mathrm{~mm}$ using WhirlPak $^{\circledR}$ bags.

In the cold room, the ice core was sectioned and decontaminated using a modified bandsaw (stainless-steel blades; tabletops and saw guides covered with Teflon), which was regularly cleaned with ethyl alcohol and 
ultrapure water $(18.2 \mathrm{M} \Omega)$. Preparation for sampling involved cutting the ice-core sections longitudinally into halves. One half-section of the core was cut into $50 \mathrm{~mm}$ segments above $80 \mathrm{~m}$ depth and into $40 \mathrm{~mm}$ segments between 80 and $144 \mathrm{~m}$ depth. The bottommost ice sections below $144 \mathrm{~m}$ were cut into $30 \mathrm{~mm}$ segments. A total of 3585 samples was collected for $\delta^{18} \mathrm{O}$, major-ion and trace element analyses. The other half-section of the core was cut into $70 \mathrm{~mm}$ (average) segments (1978 samples in total) for mercury and microparticle analyses. To obtain the radioactivity of ${ }^{210} \mathrm{~Pb}, 40$ samples of ice chips were collected from the top of the core to $40 \mathrm{~m}$ depth at $1 \mathrm{~m}$ intervals.

To eliminate possible contamination from drilling or storage, the outer portion of each ice sample was scraped using a ceramic knife in a clean, low-temperature room $\left(-8^{\circ} \mathrm{C}\right)$. Polypropylene clean-room suits and non-powder vinyl clean-room gloves were worn throughout the sampling process to minimize potential contamination (Kang and others, 2007). After the outer section of the ice was removed, the samples were put into Whirl-Pak ${ }^{\circledR}$ bags and melted at room temperature at the SKLCS, and the water was poured into high-density polyethylene vials for the subsequent experiments.

\subsection{Sample measurements}

Analysis of the $\delta^{18} \mathrm{O}$ values was performed with a MAT-253 isotope mass spectrometer $( \pm 0.1 \%$ precision $)$ using the standard $\mathrm{CO}_{2}$ equilibration technique at the Key Laboratory of Tibetan Environment Changes and Land Surface Processes, Institute of Tibetan Plateau Research, Chinese Academy of Sciences (http://www.tel.itpcas.ac.cn). All data were reported in the standard $\delta$ notation relative to Vienna Standard Mean Ocean Water, defined as

$$
\delta=\frac{\left[{ }^{18} \mathrm{O}\right]_{\text {sample }}-\left[{ }^{18} \mathrm{O}\right]_{\text {standard }}}{\left[{ }^{18} \mathrm{O}\right]_{\text {standard }}} \times 10^{3}
$$

where $\left[{ }^{18} \mathrm{O}\right]$ is the absolute content of ${ }^{18} \mathrm{O}$ in the sample or the standard water.

Soluble major ions $\mathrm{Na}^{+}, \mathrm{K}^{+}, \mathrm{Mg}^{2+}, \mathrm{Ca}^{2+}, \mathrm{Cl}^{-}, \mathrm{SO}_{4}{ }^{2-}$, $\mathrm{NO}_{3}{ }^{-}$) were measured at the University of Maine using Dionex DX-500 ion chromatographs (Grigholm and others, 2009). Elements (Al, S, Ca, Ti, V, Cr, Mn, Fe, Co, Sr, Cs, Ba, $\mathrm{La}, \mathrm{Ce}, \mathrm{Pr}, \mathrm{Nd}, \mathrm{Sm}, \mathrm{Eu}, \mathrm{Tb}, \mathrm{Dy}, \mathrm{Ho}, \mathrm{Er}, \mathrm{Tm}, \mathrm{Yb}, \mathrm{Lu}, \mathrm{Tl}, \mathrm{Bi}, \mathrm{U})$ were determined via inductively coupled plasma sectorfield mass spectrometry (ICP-SFMS) at the University of Maine. Details of the experimental procedure are provided by Kaspari and others (2009). The tritium $\left({ }^{3} \mathrm{H}\right)$ data were quantified at the Institute of Geological and Nuclear Science, National Isotope Centre, New Zealand. Tritium concentrations are usually expressed as tritium units (TU), with $1 \mathrm{TU}$ corresponding to a ratio of tritium to total hydrogen $\left(1 \mathrm{TU}=\mathrm{T} / \mathrm{H}=10^{-18}\right)$ (Morgenstern and Taylor, 2009). The ${ }^{210} \mathrm{~Pb}$ activity was indirectly analysed by measuring the $\alpha$ decay of ${ }^{210} \mathrm{Po}$ at an energy of $5.3 \mathrm{MeV}$ using alpha-spectrometry at the Paul Scherrer Institut, Switzerland (Eichler and others, 2000).

\section{ICE-CORE DATING}

The Geladaindong mountain ice core was dated using multiple approaches, including annual-layer counting (ALC, based on the seasonal cycles of $\delta^{18} \mathrm{O}$, major ions, and elements), stratigraphic markers of ${ }^{3} \mathrm{H}$ and ${ }^{210} \mathrm{~Pb}$ radioactivity, and volcanic events, as well as a flow model.
Based on the distinct seasonality of $\delta^{18} \mathrm{O}$, ions and elements (Zhang and others, 2007; Kang and others, 2010), ALC of the Geladaindong ice-core chemistry was performed by identifying seasonal cycles of $\delta^{18} \mathrm{O}, \mathrm{Al}, \mathrm{Fe}, \mathrm{Ca}, \mathrm{Ca}^{2+}, \mathrm{Cl}^{-}$ and $\mathrm{SO}_{4}{ }^{2-}$ (Fig. 2a). Tritium analysis reveals a clear peak (684 TU) at $5.74 \mathrm{~m}$ depth (Fig. 2a), which is attributed to the 1963 global atmospheric ${ }^{3} \mathrm{H}$ maximum that resulted from nuclear testing (Beck and Bennett, 2002). The 1963 depth is employed as a dating horizon, from which the annual layers are counted upward and downward. Figure $2 \mathrm{~b}$ illustrates that even in the deeper part of the core, seasonal cycles are still distinct. Based on the ${ }^{3} \mathrm{H}$ peak anchoring, the top layer of the ice core is counted upward to 1982 and the layer at 109.93 m depth backward to 1477 .

An independent depth-age scale developed using ${ }^{210} \mathrm{~Pb}$ dating, which is anchored using the known age and depth of the tritium horizon, suggests a surface dating of $\sim 1982 \pm$ 5 years and supports the ALC dating results (Fig. 3a) (Kang and others, 2015). The ${ }^{210} \mathrm{~Pb}$ is a naturally occurring radioactive isotope with a half-life of 22.3 years that is produced in the ${ }^{238} \mathrm{U}$ decay chain. Due to radioactive decay, the activity of ${ }^{210} \mathrm{~Pb}$ decreases with depth and can therefore be used for dating. The time period accessible for dating is determined mainly by the half-life and the local concentration in the atmosphere (higher at continental than at marine sites) and was found to be on a century timescale (Gäggeler and others, 1983). The ${ }^{210} \mathrm{~Pb}$ activity was indirectly measured from the $\alpha$-decay of its granddaughter nuclide ${ }^{210}$ Po electrolytically deposited on Ag plates at an energy of $5.3 \mathrm{MeV}$ using an alpha-spectrometer (Enertec Schlumberger 7164) with PIPS (Passivated Implanted Planar Silicon) detectors at the Paul Scherrer Institut (Gäggeler and others, 1983). Details of the age-depth relations are provided by Kang and others (2015).

The 1982 surface dating suggests that $\sim 23$ years of accumulation have been lost due to ablation (Kang and others, 2015). Pre-1980s temperatures were much lower than those of the last three decades observed at the meteorological stations near the study region (You and others, 2010). The glacier melting (retreat) mainly occurred since the 1990s due to the warming verified by the data collected at Ürümqi glacier No. 1, Tien Shan. The mass balance of Ürümqi glacier No. 1 generally fluctuated around zero from the 1950s to the early 1980s, while it was more negative from 1996 to 2010 (-600 mmw.e.) (Zhang and others, 2014). The mass balance of Xiaodongkemadi glacier near Geladaindong mountain was positive until the early 1990s and then turned continuously negative (Fujita and others, 2000; Pu and others, 2008; Yao and others, 2012). The consistent mass-balance deficit since the 1990 s indicates that the earlier accumulated mass from the 1980s melted, resulting in no net accumulation on Geladaindong mountain since the 1980s. Kang and others (2015) provide more detailed discussions of the mass loss since the 1980s.

For the ice accumulated before the 1980s on Geladaindong mountain, the chemical signals appear to be well preserved, with seasonality as shown in Figure 2. There were no indications of melt, as evidenced by the clear seasonal glaciochemical structure and the absence of a major soluble ion elution sequence, which was present when melt relocation had occurred. Although the $0.78 \mathrm{~m}$ of snow in the snow pit might represent only 1 year of conversion of snow to ice, meltwater did not appear to 
a

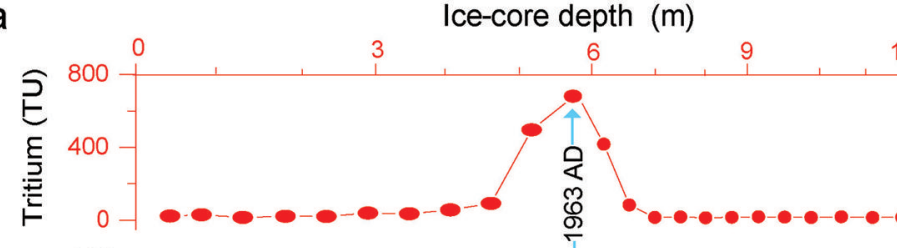
12
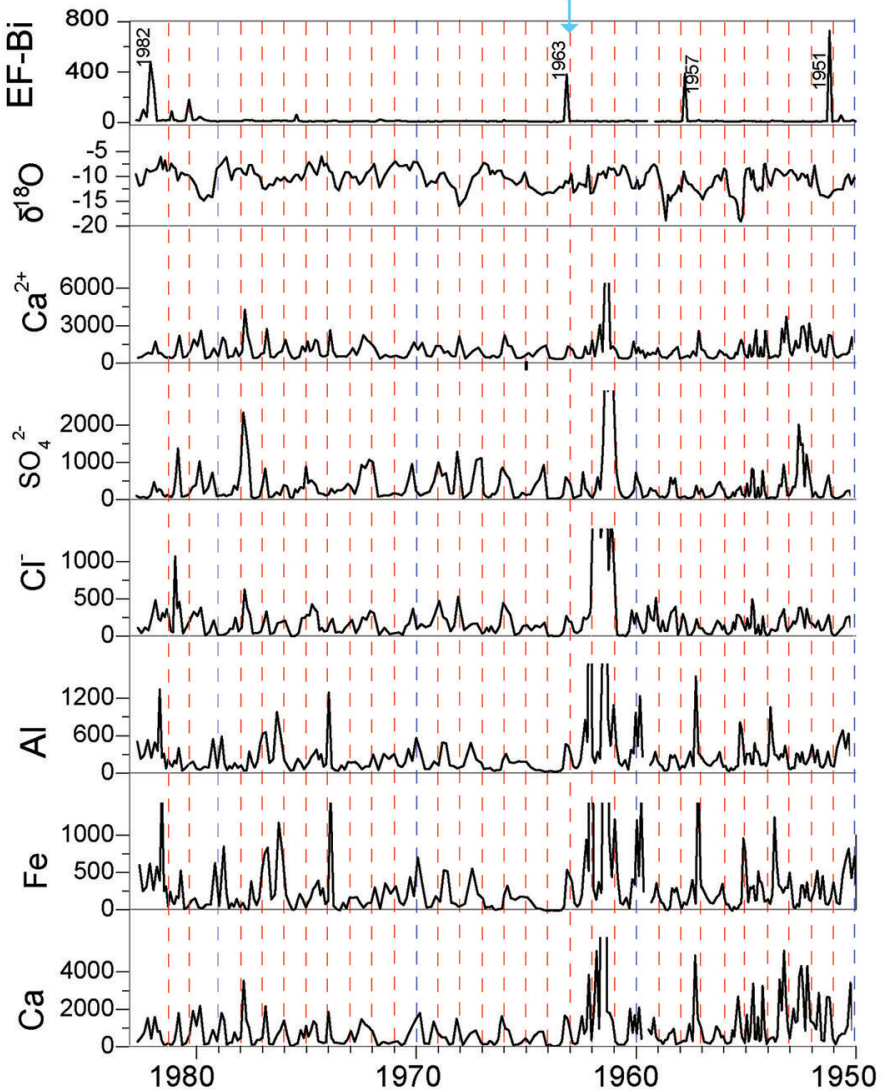

Age (AD)

b

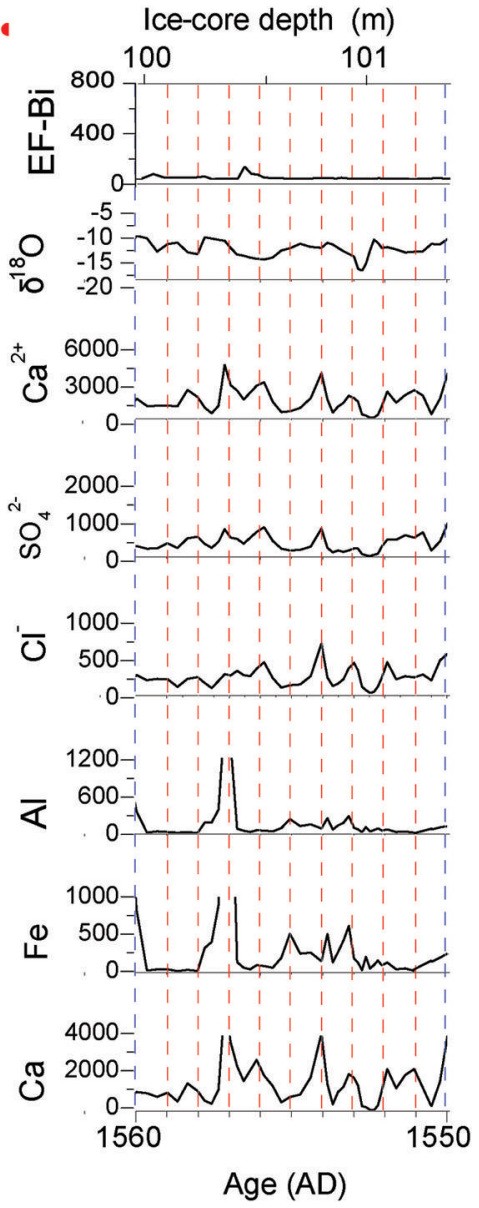

Fig. 2. (a) Upper Geladaindong ice-core dating using selected chemical species (at depth approximately 1.5-11.5 m) and the bomb peak of ${ }^{3} \mathrm{H}$ at AD 1963, and (b) deeper Geladaindong ice-core dating using selected chemical species (at depth approximately 99.9-101.4 m).

disturb the layers deposited in previous years. This is supported by work done by Eichler and others (2001) and Nakazawa and Fujita (2006).

Kang and others (2007) reconstructed summer temperature variations for the period 1935-2005 of Core A from Guoqu glacier, Geladaindong mountain. Core B was located $\sim 800 \mathrm{~m}$ southwest of the Core A site (Fig. 1). Based on field observations, the Core B site was located in an area of southward ice flow with a very slight slope outside of any ice flow confluence. Further, no evidence of water (or melting layers) was found during coring. It is suspected that the slight slope at the Core B site may cause meltwater to flow away from the site, thus losing the record of the recent decades from the ice core. However, the flat area of Core A may not lose any mass from runoff, even when summer melting occurs. The differences in the ice vertical structure between the two sites may need to be investigated using in situ radar surveys.

The bismuth enrichment factor (EF-Bi), calculated as a ratio of bismuth to the standard materials of $[\mathrm{Al}+\mathrm{Fe}+\mathrm{Ca}]$, is an effective marker for volcanic events in the TP (Kaspari and others, 2009; Xu and others, 2009). The EF-Bi showed several peaks that corresponded to volcanic eruptions (Fig. 3b) and was also used to validate $\mathrm{ACL}$ dating results.
Dating by ALC became impractical with increasing depth of the ice core due to the layer-thinning effect, thus requiring that a flow model be applied for dating the deeper part of the ice core (Kaspari and others, 2008). To describe the observed thinning effect, a flow model following Kaspari and others (2008) and Nye (1963) was used:

$$
\begin{gathered}
t=\frac{H^{m}}{(m-1) W_{\mathrm{s}}}\left[\frac{1}{(H-z)^{m-1}}-\frac{1}{H^{m-1}}\right](m \neq 1) \\
t=\frac{H}{W_{\mathrm{s}}} \ln \left[\frac{H}{H-z}\right](m=1)
\end{gathered}
$$

where $t$ is time in years, $W_{\mathrm{s}}$ is the vertical velocity at the surface, $H$ is the glacier thickness (assumed to be $150 \mathrm{~m}$ ), $\mathrm{m}$ is a parameter of vertical strain rate, $z$ is the depth below the surface of the ice core and $W_{\mathrm{s}}$ is the annual-layer thickness. If $m=1$, taking into account no dynamical ice flow, Eqn (3) implies a uniform vertical strain rate and, therefore, a constant horizontal velocity along any vertical line in the glacier. Melting at the bottom was assumed to be negligible. Using least-squares to fit Eqn (2) to the ALC age-depth profile yields $m=1.01$ and $W_{\mathrm{s}}=0.39 \mathrm{~m} \mathrm{a}^{-1}$ as the optimum values ( $m$ ranged from 1.01 to $1.60, W_{\mathrm{s}}$ ranged from 0.25 to $\left.0.68 \mathrm{~m} \mathrm{a}^{-1}\right)$. The lower value of $m$ indicates that the vertical 
a
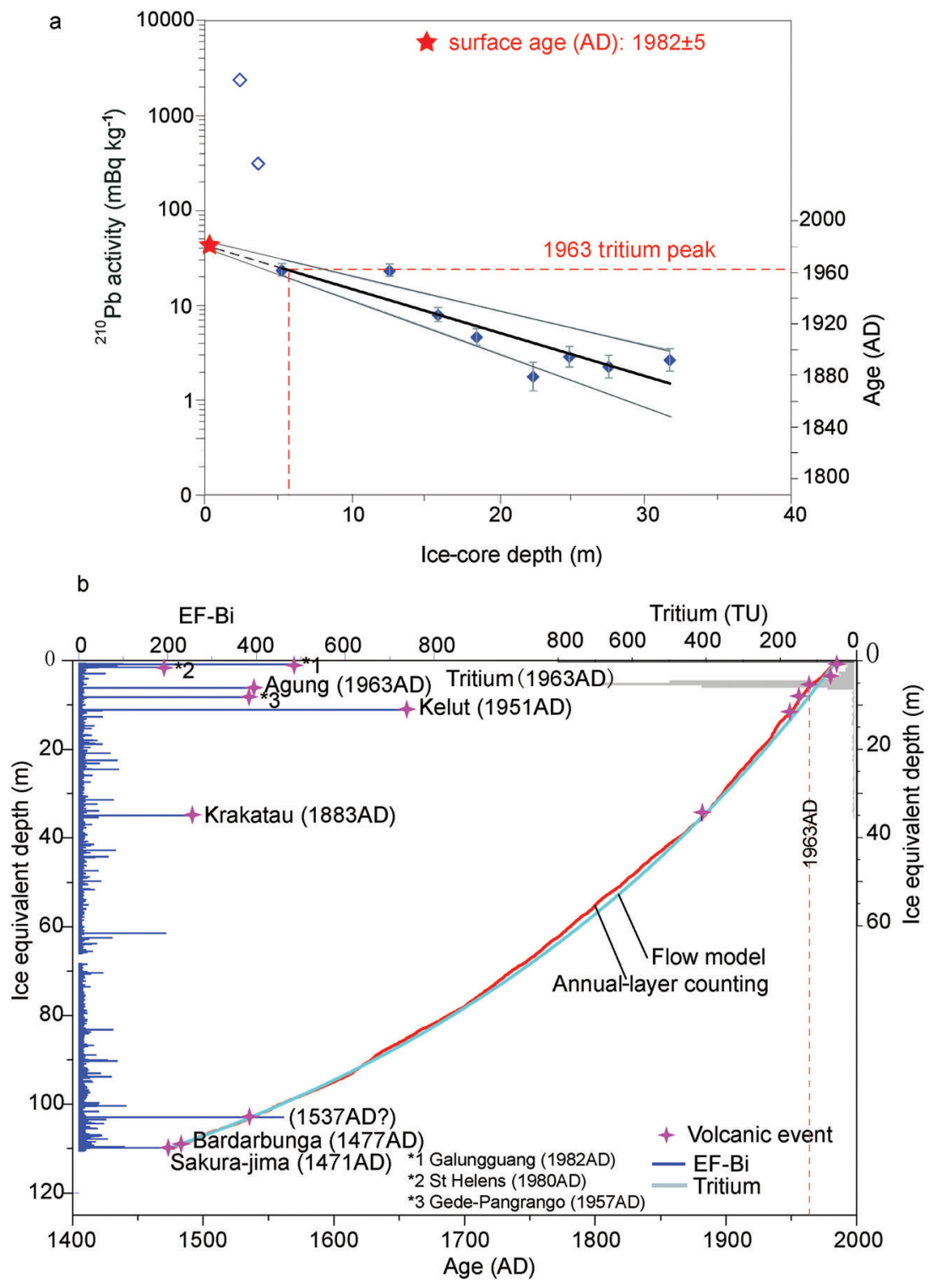

Fig. 3. (a) ${ }^{210} \mathrm{~Pb}$ activity (left axis) and age (right axis) versus depth relationship for the Geladaindong ice core. The ${ }^{210} \mathrm{~Pb}$ age-depth relationship was derived from an exponential regression of ${ }^{210} \mathrm{~Pb}$ activity against depth using the radioactivity decay law with the half-life of ${ }^{210} \mathrm{~Pb}$ of 22.3 years (Gäggeler and others, 1983). The uppermost two samples (open diamonds) were excluded because of enrichment due to melt. Error bars and the fine grey lines indicate $1 \sigma$ uncertainty of the obtained ages related to the axis on the right. This figure is reproduced from Kang and others (2015). (b) Multi-approach dating of the Geladaindong ice core, including age-depth profile calculated by annuallayer counting (red solid line), flow modelling (light blue solid line; with $m=1.01$ and $W_{\mathrm{s}}=0.39 \mathrm{~m}$ w.e. $\mathrm{a}^{-1}$ ), ${ }^{3} \mathrm{H}$, and volcanic chronology with bismuth enrichment factors (EF-Bi).

strain rates were nearly constant over much of the depth of Guoqu glacier. It also indicates that most of the velocity decrease occurred near the bottom of the glacier. This model was successfully used to simulate the Geladaindong ice-core dating down to depth $H(147 \mathrm{~m})$. Figure $3 \mathrm{~b}$ shows the age-depth relationship of the ice core established by multi-parameters. The ice-core dating uncertainty is \pm 1 year through $\mathrm{AD} 1963, \pm 5$ years through $1872, \pm 10$ years through AD 1600, and \pm 20 years through AD 1477 .

\section{RESULTS AND DISCUSSION}

\subsection{Comparison of $\delta^{18} \mathrm{O}$ records with the instrumental data}

The $\delta^{18} \mathrm{O}$-temperature relationship has been effectively used to reconstruct past climatic conditions in polar regions (e.g. Jouzel and others, 2003) and even in mid- to lowlatitude ice-core studies (e.g. Thompson and others, 2000; Kang and others, 2007; Yao and others, 2007). To evaluate the climatological significance of the Geladaindong ice-core $\delta^{18} \mathrm{O}$ records, five meteorological stations were selected in the central TP (Fig. 1) to investigate the correlations between the ice-core $\delta^{18} \mathrm{O}$ records and air temperature. From the 1950 s to the 1980s, the annual $\delta^{18} \mathrm{O}$ records were positively correlated with the average annual temperature records from the five stations $(r=0.31, p<0.1)$, while the 5 year smoothing values revealed a more significant positive relationship $(r=0.85, p<0.01)$ (Fig. 4). The relatively high temperatures in the 1970s generally corresponded to less negative $\delta^{18} \mathrm{O}$ values, whereas the relatively low temperatures in the mid-1960s were associated with more negative $\delta^{18} \mathrm{O}$ values. The $\delta^{18} \mathrm{O}$ and temperature records after the 1980s cannot be compared since the ice-core records are 


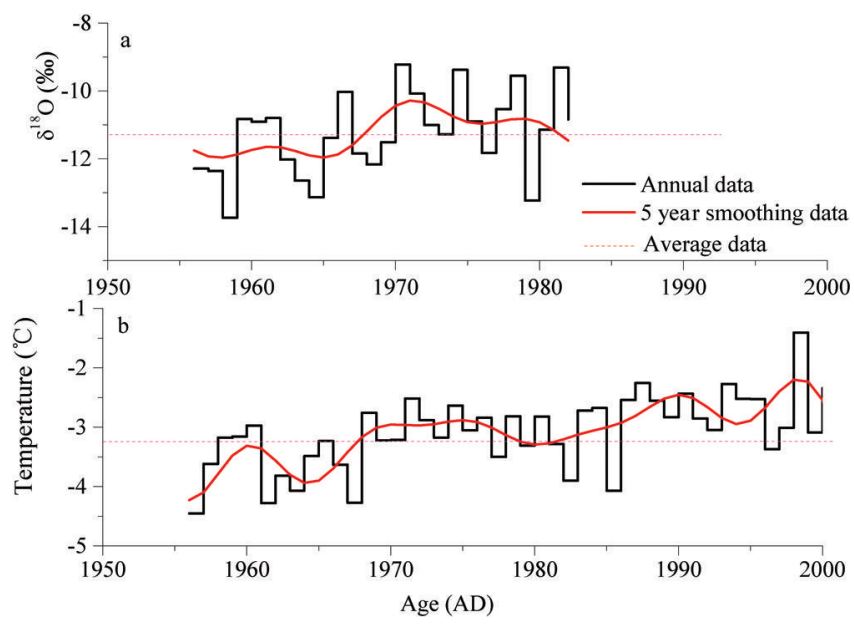

Fig. 4. (a) Annual $\delta^{18} \mathrm{O}$ values recorded in the Geladaindong ice core compared with (b) average annual temperature from five meteorological stations in the central TP.

not available. The positive correlation during the period of overlap of the ice-core $\delta^{18} \mathrm{O}$ and temperature records suggests that the ice-core $\delta^{18} \mathrm{O}$ record can be used as a proxy for annual temperature in the central TP.

On the other hand, Joswiak and others (2010) reported that there was no significant correlation between the annual $\delta^{18} \mathrm{O}$ records from an ice core drilled at Longxia Zailongba glacier in the Tanggula mountains (elevation $5743 \mathrm{~m}$ ) and the temperature from nearby meteorological stations, which was attributed to the impact of monsoon precipitation.
However, the average annual net accumulation of $261 \mathrm{~mm}$ w.e. $\mathrm{a}^{-1}$ during 1935-2003 retrieved from this ice core was much lower than the precipitation observed from nearby stations $\left(\sim 400 \mathrm{~mm}\right.$ w.e. $\left.\mathrm{a}^{-1}\right)$ and the annual net accumulation from Geladaindong ice core $\left(392 \mathrm{mmw}^{\mathrm{m}} \mathrm{e} \cdot \mathrm{a}^{-1}\right.$; 1477-1982). This indicates that mass loss may be occurring at the Longxia Zailongba ice-core site, which could affect the relationship between ice-core $\delta^{18} \mathrm{O}$ and temperature. Kang and others (2007) reconstructed a history of summer air temperatures for the past 70 years based on a significant positive relationship between the Geladaindong mountain Core $\mathrm{A} \delta^{18} \mathrm{O}$ records (Fig. 1) and summer air temperature. The differences may be attributed to the complicated topography of the ice-core drilling sites.

\subsection{0 year temperature history}

During the past $\sim 500$ years (1477-1982), the entire Geladaindong $\delta^{18} \mathrm{O}$ profile was characterized by interannual variability and a gradually increasing temperature trend, with the rate of warming accentuated in the 20th century (Fig. 5). As illustrated by the 10 year average $\delta^{18} \mathrm{O}$ values (Fig. 5c), relatively cold periods were identified between the 1470s and the 1840s, most likely related to the LIA. Previous studies (Yang and others, 2008), which involved radiocarbon ages of fossil wood, lichen-dated moraines and trees, documented evidence of the LIA (e.g. glacial advances in the southern TP from 1400 to 1920). In the northern TP, Yao and others (1997) reported three cold periods (mainly in the 15th, 17th and 19th centuries) from the Dunde and Guliya $\delta^{18} \mathrm{O}$ records, further supported by three widely existing moraine ridges formed during the LIA.

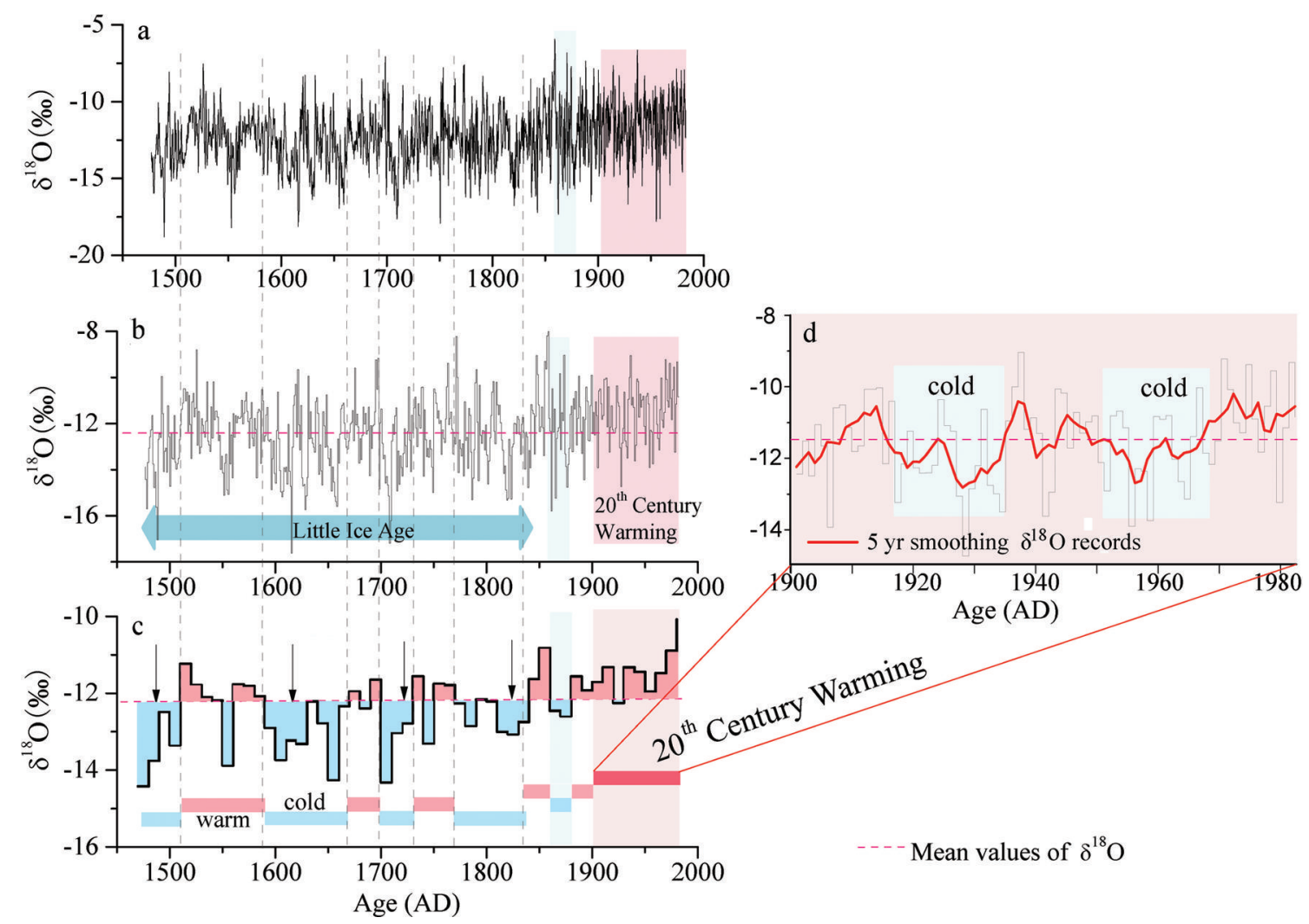

Fig. 5. Reconstructed variations from the Geladaindong ice-core $\delta^{18} \mathrm{O}$ record during the period 1477-1982. (a) Raw data; (b) annual record; (c) 10 year averaged records (vertical blue and red bar represent relatively more and less negative records, respectively. Horizontal blue and red bar represent the relatively cold and warm periods, respectively. Light red shadow represents the 20th-century warming period.); and (d) $\delta^{18} \mathrm{O}$ record in the 20th century (light-green shadow represents the relatively cold periods). 


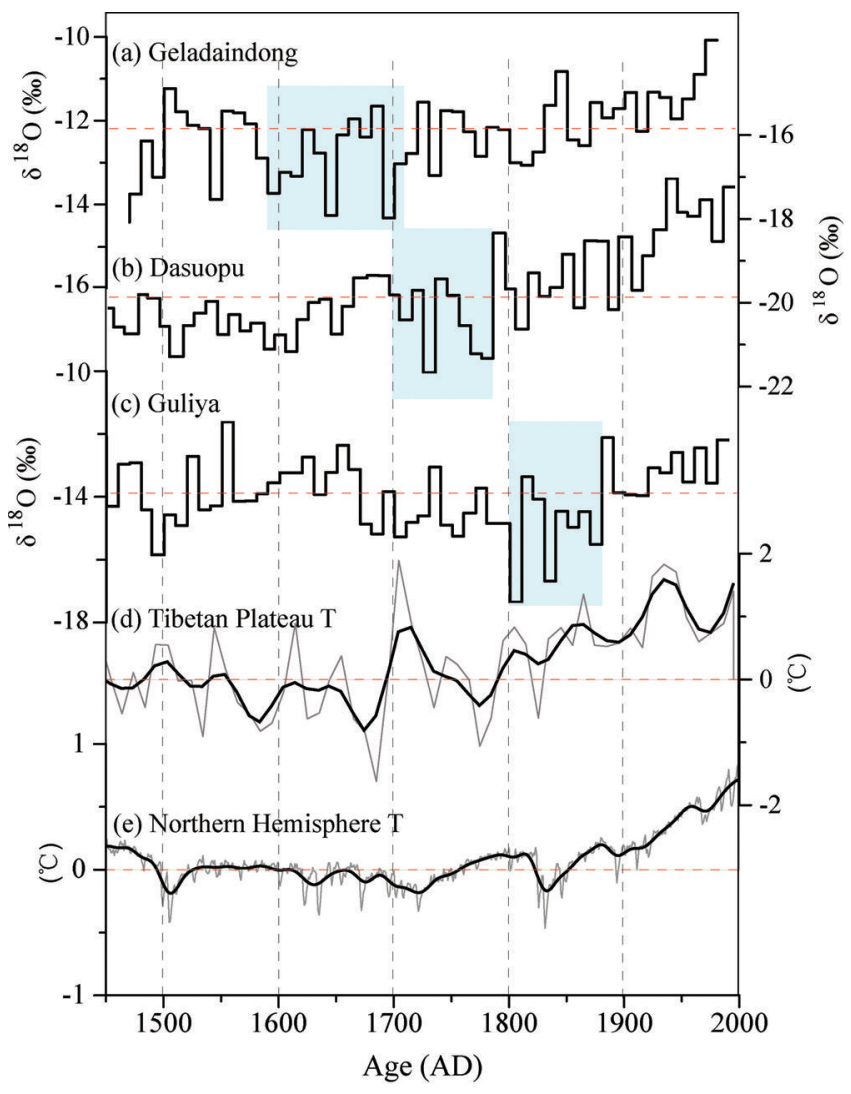

Fig. 6. Time series of $(\mathrm{a}-\mathrm{c})$ the anomalies in the $\delta^{18} \mathrm{O}$ records from (a) Geladaindong mountain, (b) Dasuopu (Thompson and others, 2000) and (c) Guliya ice cores (Yao and others, 2007), and (d, e) reconstructed temperatures for (d) the TP (Wang and others, 2007) and (e) the Northern Hemisphere (Stocker and others, 2013). Coarse lines represent the 10 year mean values. Thin lines are the annual data. Dashed lines are the average data over the periods.

The integrated ice-core records suggest that the period 1570-1880 was characterized by LIA-related cooling (Yao and others, 2007). These similar results from different parts of the TP indicate the influence of climatic conditions during the LIA over the entire TP. However, some differences in timing of the LIA on the TP may be due to differences in the regional-scale climatic and topographic conditions (Kaspari and others, 2008). During the LIA (Fig. 5c), the Geladaindong $\delta^{18} \mathrm{O}$ ice-core record indicated four relatively cold periods (1470s-1500s, 1580s-1660s, 1700s-20s and 1770s-1840s) and three relatively warm periods (1510s70s, 1670s-90s and 1730s-60s). A comparison to temperature records retrieved from other ice cores and tree-ring widths on the TP and in nearby regions shows common cold periods in the 15th century, 1625-45, 1660-1700, 1725-75 and 1795-1830, with 1725-75 corresponding to the LIA maximum (Yang and others, 2009). In southwest Tibet, the annual temperature history over the past 400 years indicates that cold conditions prevailed during the 1630s-40s, 1680s-1710s, 1730s, 1820s-40s, 1900s-20s and 1970s (Yang and others, 2010).

Glacial fluctuations on the TP indicate that periods of glacial advance during the LIA coincided with cold periods (Zhu and others, 2012). Tree-ring records in the southeastern TP indicate that Xincuo glacier reached its LIA maximum before 1876 (Zhu and others, 2012), while Midui glacier peaked in 1767 (Xu and others, 2012). Consequently, the period 1760-80 appears to represent the maximum LIA advance in this region (Bräuning and others, 2006). In the northeastern TP, LIA conditions occurred from 1400 to 1850 , interrupted by milder periods with three significant cold events (in approximately 1500, 1700 and 1850), which coincide with the advance of glaciers (Gou and others, 2006). The Geladaindong ice core indicated that the most prolonged cool period in the past 500 years occurred during the late 16th to early 18th centuries (Fig. 5); this may correspond to the LIA glacier advance in the central TP regions. $\mathrm{Xu}$ and $\mathrm{Yi}$ (2014) noted that the LIA moraines in the eastern Tanggula mountains were formed before 1809, 1857-88 and 1902, implying that the glaciers in the central Tanggula mountains may have advanced during these cold periods.

The long-term temperature variations since $A D \sim 1500$ in the Geladaindong $\delta^{18} \mathrm{O}$ record were broadly consistent with the Dasuopu $\left(28^{\circ} 23^{\prime} \mathrm{N}, 8^{\circ} 43^{\prime} \mathrm{E} ; 7200\right.$ ma.s.l.; DSP in Fig. 1a) and Guliya $\left(35^{\circ} 17^{\prime} \mathrm{N}, 81^{\circ} 29^{\prime} \mathrm{E} ; 6200 \mathrm{~m}\right.$ a.s.I.; GLY in Fig. 1a) ice-core $\delta^{18} \mathrm{O}$ records and the temperature anomalies from the whole TP and the Northern Hemisphere (Fig. 6), indicating that climate warming is a widespread phenomenon on the whole TP (Thompson and others, 2000). For instance, the Geladaindong $\delta^{18} \mathrm{O}$ records positively correlate with Northern Hemisphere temperature anomalies ( $r=0.65, p<0.01 ; 11$ year running means). However, some differences appear on decadal timescales.

During the 17th century, Geladaindong mountain experienced a much colder period, while a similar cold period occurred during the 19th century in Guliya (Yao and others, 2007); in contrast, the Dasuopu $\delta^{18} \mathrm{O}$ records are mainly characterized as a cold period through the 18th century (Thompson and others, 2000). The $\delta^{18} \mathrm{O}$-inferred temperature fluctuations at Geladaindong mountain, Guliya, and Dasuopu are generally out of phase with each other, suggesting different large-scale climate regimes on the southern, central and northwestern parts of the TP. During the monsoon season (June-September), low pressure over the plateau induces flow of moist, warm air from the Indian and Pacific Oceans to the TP (Yanai and Wu, 2005). The southern to central TP was mainly dominated by the Indian monsoon. Precipitation $\delta^{18} \mathrm{O}$ in the monsoon domain experienced an abrupt decrease in May and the greatest depletion in August, attributable to the shifting moisture origin between the Bay of Bengal and the southern Indian Ocean (Yao and others, 2013). During the non-monsoon season, high pressure drove cold and dry air out of the plateau (Yanai and Wu, 2005). The moisture was mainly transported by the westerlies, resulting in the marked west-east TP $\delta^{18} \mathrm{O}$ gradient (Yao and others, 2013). Precipitation in the westerly domain was correlated to temperature. Marine air masses transported from the southwest cannot directly reach the northern TP (Tian and others, 2001a), where continental recycling enhanced by evaporation over the land surface was significant and enriched summer precipitation $\delta^{18} \mathrm{O}$ (Tian and others, 2001b). Simulation results from REMOiso and zoomed LMDZiso models clearly depicted close links between seasonal variations of $\delta^{18} \mathrm{O}$ and the moisture sources and transport pathways (Yao and others, 2013).

The most common characteristics between the Geladaindong $\delta^{18} \mathrm{O}$ records and the other ice-core records are related to the apparent influences of the LIA and 20th-century warming. Because climatic changes were linked to external forcing factors (e.g. solar activity or volcanic eruptions) combined with continental atmospheric circulation, which was affected by the complex regional meteorology (Stocker 
and others, 2013), the reconstructed records exhibit differences in the timing, magnitude and duration of cold and warm periods. From the analyses of the four ice-core $\delta^{18} \mathrm{O}$ records in the TP, Yao and others (2007) attributed these discrepancies to regional climate changes and the systematic differences in climate variations in the southern and northern TP. To better explore the potential impact of atmospheric circulation on the Geladaindong ice-core records, the relationship between the $\delta^{18} \mathrm{O}$ record and the North Atlantic Oscillation (NAO) is investigated in Section 4.4.

\subsection{Twentieth-century warming}

The Geladaindong $\delta^{18} \mathrm{O}$ profile suggests relatively high temperatures during the 1870s-80s (Fig. 5c) near the end of the LIA. In the 20th century, the increasing $\delta^{18} \mathrm{O}$ values indicate a prolonged, dramatic warming trend, corresponding to the warmest periods over the past 500 years. The 20th century was punctuated by two relatively cold periods (1917-34 and 1951-67) and three warm periods (1900-16, 1935-50 and 1968-82) (Fig. 5d). After the 1960s, temperatures increased rapidly, with a mild cool period in the late 1970s. The Guliya core indicates more distinct increasing temperatures, with warm periods occurring later than those at Geladaindong mountain, while the Dasuopu ice core indicates cold periods during the 1910s and 1960s (Yao and others, 2006). Nevertheless, the broadly similar positive trends in temperature from all 20th-century ice-core records suggest large-scale warming occurred on the TP (Yao and others, 2007). The distinct cold period during the 1920s at Geladaindong mountain coincided with dramatic climatic changes on the TP, such as the drying of the northeastern TP (Liang and others, 2009) and glacial advances (Bräuning, 2006; $\mathrm{Xu}$ and others, 2012).

Warming in the 20th century has caused most of the glaciers on the TP to shrink; no net accumulation of ice mass has occurred on Naimona'nyi glacier since 1950 (Kehrwald and others, 2008), nor has accumulation occurred on Guoqu glacier (Core B) since the 1980s (Kang and others, 2015). This rapid glacial retreat and thinning not only contributed to global sea-level rise (Radić and Hock, 2011), but also threatened freshwater supplies (including irrigation and hydropower) downstream along major Asian rivers (Immerzeel and others, 2010). In the Yangtze River source region (Geladaindong mountain region), glaciers have also experienced noticeable shrinkage in the past half-century (Ye and others, 2006). This may be one reason why the most recent layer of the Geladaindong ice core only corresponds to the 1980s (Kang and others, 2015).

\subsection{Teleconnection with North Atlantic Oscillation}

To explore the potential impact of atmospheric circulation on the Geladaindong ice-core records, the relationship between the ice-core $\delta^{18} \mathrm{O}$ record and the $\mathrm{NAO}$ was investigated. The NAO is a large-scale seesaw in the atmospheric mass between the Arctic and the subtropical Atlantic. This process is the dominant mode of winter variability in the North Atlantic region and exerts significant influence on climate over the Northern Hemisphere (Hurrell and others, 2001). The NAO has been found to directly affect many areas, including agricultural yields, water management and fish inventories. A positive NAO index phase shows a deeper than normal Iceland low-pressure centre and a stronger than usual subtropical high-pressure centre in the Azores, suggesting that the winter meridional

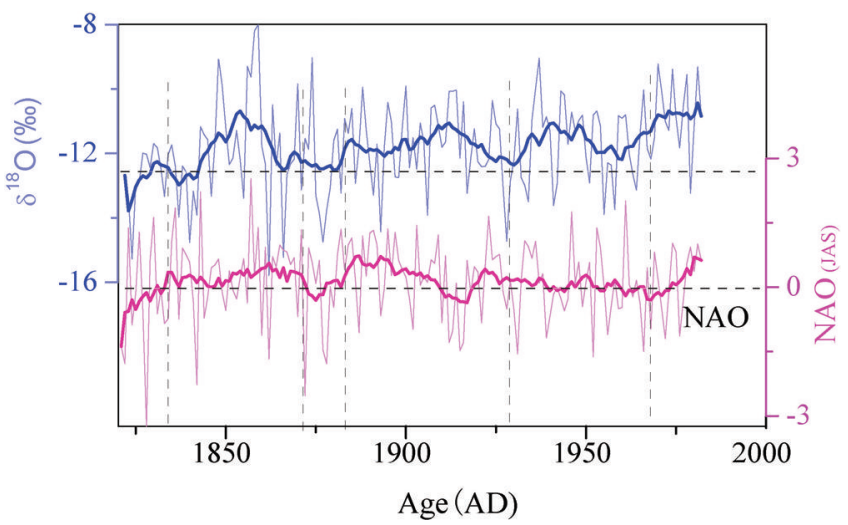

Fig. 7. Comparison of the Geladaindong ice-core $\delta^{18} \mathrm{O}$ record (blue line) with the NAO index (pink line) from July to September (JAS; from Jones and others, 1997) during the period 1821-1982. Coarse lines represent the 10 year smoothing means.

pressure gradient over the North Atlantic is larger. Both centres are weakened during an NAO negative phase. The transition of pressure gradients generates marked variations of heat and moisture transport between the Atlantic and the surrounding continents, including Asia (Hurrell and others, 2001; Yu and Zhou, 2004). The NAO can reflect the change in the intensity of westerlies (Jones and others, 2003), which control the entire TP climate in the winter and the northern TP climate in summer. Previous studies also found that the dominant pattern of interannual variability of the summer precipitation, a seesaw structure between the southern and northern TP, is correlated with the NAO (Liu and Yin, 2001). Significant associations between deuterium excess records of the Noijin Kangsang mountain ice core on the southern TP and the NAO indicate that the TP climate can be affected by the NAO via the westerlies (Zhao and others, 2011). In addition, statistically modest to weak correlations were found between $\delta^{18} \mathrm{O}$ values and the NAO index from May to October in the Malan ice core (Wang and others, 2003). A Qomolangma (Mount Everest) ice core shows a significant correlation between the winter NAO index and the mass concentrations of insoluble particles (Xu and others, 2007). These studies suggested a direct or indirect teleconnection between the atmospheric processes over the North Atlantic and the meteorological conditions of the TP.

To investigate the role of an atmospheric teleconnection in the Geladaindong temperature records, the relationships between the Geladaindong $\delta^{18} \mathrm{O}$ records and the NAO were analysed. The calculated coefficients suggest a likely linkage between annual values $(r=0.15)$ and 10 year smoothing means $(r=0.32, p<0.01)$, which is consistent with the positive relationships from the Malan ice core in the TP (Wang and others, 2003). The temporal series shown in Figure 7 depict the synchronous variations in the $\delta^{18} \mathrm{O}$ records and the summer NAO index since the 1820s. The positive correlation indicates that summer temperature may be higher over the central TP when the NAO index is positive.

The westerlies over the mid-latitudes of Asia were positively correlated with the NAO based on the US National Centers for Environmental Prediction (NCEP) reanalysis data (Wang and others, 2003). The zonal indices also had some similarities with the NAO (Allan and Ansell, 2006; Zhao and others, 2011), suggesting a positive correlation over the mid-latitudes of the Northern Hemisphere. Consequently, it is speculated that NAO increases (positive 


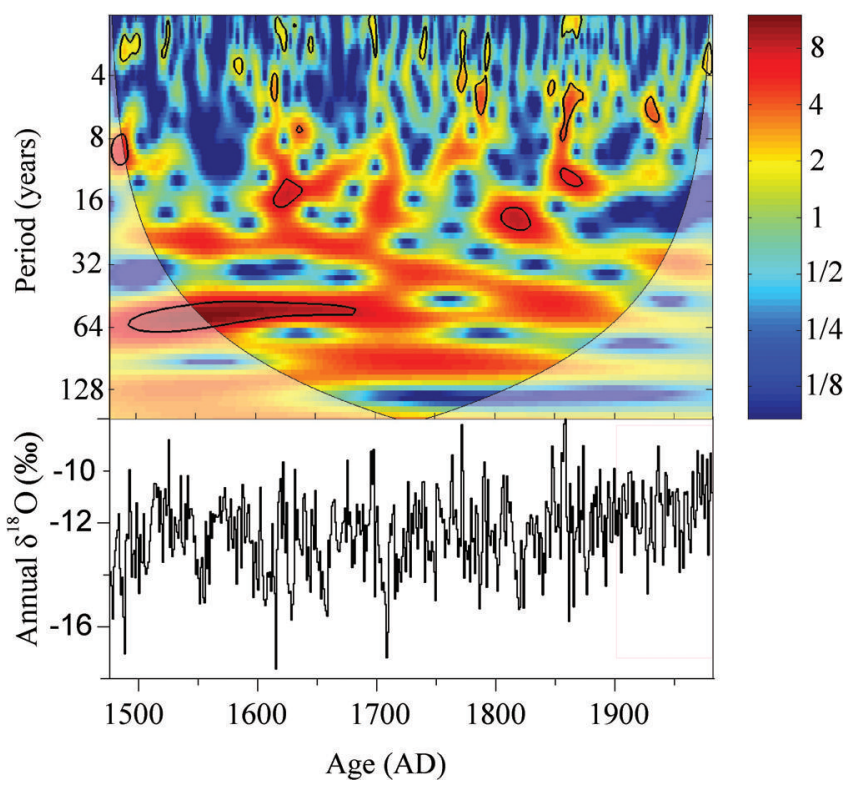

Fig. 8. Annual $\delta^{18} \mathrm{O}$ records in the Geladaindong ice core (bottom) and its continuous wavelet power spectrum (top). Thick black contour designates the $5 \%$ significance level against red noise, and the cone of influence where edge effects might distort the picture is shown as a light shading. Colour represents the power spectral function values input to the wavelet analysis.

phase) are linked to increasing $\delta^{18} \mathrm{O}$ values in the Geladaindong ice core, induced by stronger westerlies which decrease the colder air incursions from the north, and vice versa (Thompson and Wallace, 2001). Thus, a positive $\mathrm{NAO}$ indicates stronger westerlies over the mid-latitude regions of the Northern Hemisphere, which weaken cold air mass incursions over the TP and lead to the less negative $\delta^{18} \mathrm{O}$ records and relatively warm periods on the central TP.

\subsection{Wavelet spectrum of Geladaindong mountain $\delta^{18} \mathrm{O}$ records}

A wavelet spectrum of the Geladaindong ice-core $\delta^{18} \mathrm{O}$ records in Figure 8 reveals four significant periods near 6-8 years, 12-14 years (sunspot cycle), 22-25 years (Hale cycle), and 52-66 years. A spectrum analysis of the winter NAO index revealed somewhat enhanced variance at quasibiennial periods, a deficit in power at 3-6year periods, and slightly enhanced power in the 8-10 year periods over the latter half of the 20th century (Hurrell and others, 2003). The 6-8 year periods of Geladaindong ice core confirm the influence of the NAO. Previous spectral analyses of other TP ice cores suggest a sunspot cycle (Yao and others, 2006), indicating that solar activity played an important role in climate change over the TP. However, the differences in the spectral periods in the Guliya and Dasuopu records also indicated that the southern TP was mainly under the influence of the Indian monsoon, whereas the northern TP responded more to the influence of westerly cyclones and Siberian anticyclones rather than the Indian monsoon (Yao and others, 2006). The central TP is thought to be at the northern limit of influence of the Indian monsoon (Tian and others, 2007). To a certain extent, the regional differences in atmospheric circulation affect the sources of moisture and its transportation, which could be the cause of the asynchronicity of the ice-core records (Davis and others, 2005; Yao and others, 2006). These discrepancies, such as the varying temporal features of the LIA, are illustrated in Figure 6, as discussed above.

However, the cold periods indicated by the Geladaindong and other TP ice-core records do not exactly coincide with the solar activities of the Dalton Minimum (1790s-1820s), the Maunder Minimum (1640s-1710s) and the Spörer Minimum (1450s-1550s). For instance, during the Maunder Minimum, when the sun was relatively weak, the Geladaindong ice core recorded a relatively warm period from the 1670 s to the 1690s (Fig. 5). This indicates the influence of other factors such as complex mountain meteorology or iceflow dynamics (Kaspari and others, 2008).

\section{CONCLUSIONS}

Using multi-approach ice-core dating on the $\delta^{18} \mathrm{O}$ record from the Geladaindong ice core in the central TP, a 500 year record of temperature variations was reconstructed. Results indicate a slight warming trend from 1477 to 1982, punctuated by the LIA (1470s-1850s) fluctuations with relatively colder periods during the 1470s-1500s, 1580s1660s, 1700s-20s and 1770s-1840s. Since the 1850s, the $\delta^{18} \mathrm{O}$ profile is characterized by higher temperatures, with a prolonged warming in the 20th century. The LIA fluctuations and 20th-century warming of the central TP are generally consistent with those documented by ice cores from the southern and northern TP. However, the air temperature may have been higher over the central TP when the NAO index was positive, suggesting that a positive NAO may induce stronger westerlies, which partly decrease the colder air incursions from the north. A spectral analysis of the Geladaindong $\delta^{18} \mathrm{O}$ record showed notable cycles with significant peaks at 6-8 years and $12-14$ years, similar to sunspot and Hale cycles, respectively. Thus, solar activity may be one of the primary factors influencing climate changes over the TP.

\section{ACKNOWLEDGEMENTS}

This work was supported by the Global Change Research Program of China (2013CBA01801), the National Natural Science Foundation of China (41201074, 41225002, 41421061), the State Key Laboratory of Cryospheric Sciences, the Academy of Finland (decision No. 264307), the Foundation for Excellent Youth Scholars of CAREERI, CAS, and Research on Paleo Lakes Climate Variations Records in Qinghai-Tibetan Plateau (No.12120113006100). We thank all members of the Sino-US Cooperative Expedition Team in 2005 for drilling. We acknowledge D. Qu, J. Guo and K. Wang for laboratory work. We also thank H. Gäggeler for his suggestions on dating the ice core.

\section{REFERENCES}

Allan R and Ansell T (2006) A new globally-complete monthly historical gridded mean sea level pressure data set (HadSLP2): 1850-2004. J. Climatol., 19(22), 5816-5842 (doi: 10.1175/ jcli3937.1)

Beck HL and Bennett BG (2002) Historical overview of atmospheric nuclear weapons testing and estimates of fallout in the continental United States. Health Phys., 82(5), 591-608 (doi: 10.1097/ 00004032-200205000-00007)

Bräuning A (2006) Tree-ring evidence of 'Little Ice Age' glacier advances in southern Tibet. Holocene, 6(3), 369-380 (doi: 10.1191/0959683606h1922rp) 
Davis ME, Thompson LG, Yao T and Wang N (2005) Forcing of the Asian monsoon on the Tibetan Plateau: evidence from highresolution ice core and tropical coral records. J. Geophys. Res., 110, D04101 (doi: 10.1029/2004JD004933)

Eichler A and 7 others (2000) Glaciochemical dating of an ice core from upper Grenzgletscher (4200 ma.s.l.). J. Glaciol., 46(154), 507-515 (doi: 10.3189/172756500781833098)

Eichler A, Schwikowski M and Gäggeler H (2001) Meltwaterinduced relocation of chemical species in Alpine firn. Tellus $B$, 53(2), 192-203 (doi: 10.1034/j.1600-0889.2001.d01-15.x)

Fujita K, Ageta Y, Pu J and Yao T (2000) Mass balance of Xiao Dongkemadi glacier on the central Tibetan Plateau from 1989 to 1995. Ann. Glaciol., 31, 159-163 (doi: 10.3189/ 172756400781820075. 2000)

Gäggeler HW, von Gunten HR, Oeschger $\mathrm{H}$ and Schotterer U (1983) ${ }^{210} \mathrm{~Pb}$-dating of cold alpine firn/ice cores from Colle Gnifetti, Switzerland. J. Glaciol., 29(101), 165-177

Gou X, Chen F, Yang M, Jacoby G, Peng J and Zhang Y (2006) A comparison of tree-ring records and glacier variations over the past 700 years, northeastern Tibetan Plateau. Ann. Glaciol., 43, 86-90 (doi: 10.3189/172756406781812438)

Grigholm B and 6 others (2009) Atmospheric soluble dust from a Tibetan ice core: possible climate proxies and teleconnection with the Pacific Decadal Oscillation. J. Geophys. Res., 114, D20118 (doi: 10.1029/2008JD011242)

Hurrell JW, Kushnir Y and Visbeck M (2001) The North Atlantic Oscillation. Science, 291, 603-604 (doi: 10.1126/ science.1058761)

Hurrell JW, Kushnir Y, Ottersen G and Visbeck M (2003) An overview of the North Atlantic Oscillation. In Hurrell JW, Kushnir Y, Ottersen G and Visbeck M eds The North Atlantic Oscillation: climatic significance and environmental impact. (Geophysical Monograph Series, 134) American Geophysical Union, Washington, DC, 1-35

Immerzeel WW, Van Beek LPH and Bierkens MEP (2010) Climate change will affect the Asian water tower. Science, 328, 13821385 (doi: 10.1126/science.1183188)

Jones PD, Jonsson T and Wheeler D (1997) Extension to the North Atlantic Oscillation using early instrumental pressure observations from Gibraltar and south-west Iceland. J. Climatol., 17(13), 1433-1450 (doi: 10.1002/(sici)1097-0088(19971115) 17:13<1433::aid-joc203>3.0.co;2-p)

Jones PD, Osborn TJ and Briffa KR (2003) Pressure-based measures of the North Atlantic Oscillation (NAO): a comparison and an assessment of changes in the strength of the NAO and its influence on surface climate parameters. In Hurrell JW, Kushnir Y, Ottersen G and Visbeck M eds The North Atlantic Oscillation: climatic significance and environmental impact. (Geophysical Monograph Series, 134) American Geophysical Union, Washington, DC, 51-62 (doi: 10.1029/134GM03)

Joswiak DR, Yao T, Wu G, Xu B and Zheng W (2010) A 70-a record of oxygen-18 variability in an ice core from the Tanggula Mountains, central Tibetan Plateau. Climate Past, 6, 219-227

Jouzel J and 6 others (2003) Magnitude of isotope/temperature scaling for interpretation of central Antarctic ice cores. J. Geophys. Res., 108(D12) (doi: 10.1029/2002JD002677)

Kang S and 6 others (2007) Recent temperature increase recorded in an ice core in the source region of Yangtze River. Chinese Sci. Bull., 52(6), 825-831 (doi: 10.1007/s11434-007-0140-1)

Kang S and 7 others (2010) Variability of atmospheric dust loading over the central Tibetan Plateau based on ice core glaciochemistry. Atmos. Environ., 44, 2980-2989 (doi: 10.1016/j.atmosenv. 2010.05.014)

Kang S and 10 others (2015) Dramatic loss of glacier accumulation area on the Tibetan Plateau revealed by ice core tritium and mercury records. Cryosphere, 9, 1-10 (doi: 10.5194/tc-9-12015)

Kaspari S, Hooke RLeB, Mayewski PA, Kang SC, Hou SG and Qin $\mathrm{DH}$ (2008) Snow accumulation rate on Qomolangma (Mount Everest), Himalaya: synchroneity with sites across the Tibetan
Plateau on 50-100 year timescales. J. Glaciol., 54(185), 343-352 (doi: 10.3189/002214308784886126)

Kaspari S and 7 others (2009) Recent increases in atmospheric concentrations of $\mathrm{Bi}, \mathrm{U}, \mathrm{Cs}, \mathrm{S}$ and Ca from a 350-year Mount Everest ice core record. J. Geophys. Res., 114, D04302 (doi: 10.1029/2008JD011088)

Kehrwald NM and 8 others (2008) Mass loss on Himalayan glacier endangers water resources. Geophys. Res. Lett., 35, L22503 (doi: 10.1029/2008GL035556)

Li J and 6 others (1986) Glaciers in Tibet. Science Press, Beijing

Liang E, Shao X and Liu X (2009) Annual precipitation variation inferred from tree rings since A.D. 1770 for the western Qilian Mts., northern Tibetan Plateau. Tree-Ring Res., 65(2), 95-103 (doi: 10.3959/2008-2.1)

Liu X and Yin Z (2001) Spatial and temporal variation of summer precipitation over the eastern Tibetan Plateau and the North Atlantic oscillation. J. Climate, 14, 2896-2909 (doi: 10.1175/ 1520-0442(2001)014<2896:satvos>2.0.co;2)

Morgenstern U and Taylor CB (2009) Ultra low-level tritium measurement using electrolytic enrichment and LSC. Isot. Environ. Health Stud., 45(2), 96-117 (doi: 10.1080/ 10256010902931194)

Nakazawa F and Fujita K (2006) Use of ice cores from glaciers with melting for reconstructing mean summer temperature variations. Ann. Glaciol., 43, 167-171 (doi: 10.3189/ 172756406781812302)

Nye J (1963) Correction factor for accumulation measured by the thickness of the annual layers in an ice sheet. J. Glaciol., 4(36), 785-788

Pu J and 6 others (2008) Rapid decrease of mass balance observed in the Xiao (Lesser) Dongkemadi Glacier, in the central Tibetan Plateau. Hydrol. Process., 22(16), 2953-2958 (doi: 10.1002/ hyp.6865)

Radić V and Hock R (2011) Regionally differentiated contribution of mountain glaciers and ice caps to future sea-level rise. Nature Geosci., 4(2), 91-94 (doi: 10.1038/NGEO1052)

Shi Y (2008) Concise glacier inventory of China. Shanghai Popular Science Press, Shanghai

Stocker TF and 9 others eds (2013) Climate change 2013: the physical science basis. Contribution of Working Group 1 to the Fifth Assessment Report of the Intergovernmental Panel on Climate Change. Cambridge University Press, Cambridge and New York

Thompson DWJ and Wallace JM (2001) Regional climate impacts of the Northern Hemisphere annular mode. Science, 293(5527), 85-89 (doi: 10.1126/science.1058958)

Thompson LG, Yao T, Mosley-Thompson E, Davis ME, Henderson KA and Lin P-N (2000) A high-resolution millennial record of the south Asian monsoon from Himalayan ice core. Science, 289(5486), 1916-1919 (doi: 10.1126/science.289. 5486.1916)

Thompson LG and 6 others (2006a) Ice core evidence for asynchronous glaciation on the Tibetan Plateau. Quat. Int., 154-155, 3-10 (doi: 10.1016/j.quaint.2006.02.001)

Thompson LG and 7 others (2006b) Holocene climate variability archived in the Puruogangri ice cap on the central Tibetan Plateau. Ann. Glaciol., 43, 61-67 (doi: 10.3189/ 172756406781812357)

Tian L, Yao T, Sun W, Stievenard W and Jouzel J (2001a) Relationship between delta D and delta O-18 in precipitation on north and south of the Tibetan Plateau and moisture recycling. Sci. China, Ser. D, 44(9), 789-796 (doi: 10.1007/ Bf02907091)

Tian L, Masson-Delmotte V, Stievenard M, Yao T and Jouzel J (2001b) Tibetan Plateau summer monsoon northward extent revealed by measurements of water stable isotopes. J. Geophys. Res., 106(D22), 28 081-28 088 (doi: 10.1029/2001JD900186)

Tian $L$ and 7 others (2007) Stable isotopic variations in west China: a consideration of moisture sources. J. Geophys. Res., 112, D10112 (doi: 10.1029/2006JD007718) 
Wang N, Thompson LG, Davis ME and Mosley-Thompson E (2003) Influence of variations in $\mathrm{NAO}$ and $\mathrm{SO}$ on air temperature over the northern Tibetan Plateau as recorded by $\delta^{18} \mathrm{O}$ in the Malan ice core. Geophys. Res. Lett., 30, 222167 (doi: 10.1029/ 2003GL018188)

Wang S, Wen X, Luo Y, Dong W, Zhao C and Yang B (2007) Reconstruction of temperature series of China for last 1000 years. Chinese Sci. Bull., 52(23), 3272-3280 (doi: 10.1007/ s11434-007-0425-4)

$\mathrm{Xu} \mathrm{J}$ and 6 others (2007) Dust storm activity over the Tibetan Plateau recorded by a shallow ice core from the north slope of Mt. Qomolangma (Everest), Tibet-Himalayan region. Geophys. Res. Lett., 34, L17504 (doi: 10.1029/2007GL030853)

Xu J, Kaspari S, Hou S, Kang S, Qin D, Ren J and Mayewski PA (2009) Records of volcanic events since AD 1800 in the East Rongbuk ice core from Mt. Qomolangma. Chinese Sci. Bull., 54(8), 1411-1416 (doi: 10.1007/s11434-009-0020-y)

Xu P, Zhu H, Shao X and Yin Z (2012) Tree ring-dated fluctuation history of Midui glacier since the Little Ice Age in the southeastern Tibetan Plateau. Sci. China (Earth Sci.), 55(4), 521-529 (doi: 10.1007/s11430-011-4338-3)

Xu X and Yi C (2014) Little Ice Age on the Tibetan Plateau and its bordering mountains: evidence from moraine chronologies. Global Planet. Change, 116, 41-53 (doi: 10.1016/j.gloplacha.2014.02.003)

Yanai M and Wu G (2005) Effects of the Tibetan Plateau. In Wang B ed. The Asian Monsoon. Springer, Berlin, 513-549

Yang B, Bräuning A, Dong Z, Zhang Z and Jiao K (2008) Late Holocene monsoonal temperature glacier fluctuations on the Tibetan Plateau. Global Planet. Change, 60, 126-140 (doi: 10.1016/j.gloplacha.2006.07.035)

Yang B, Bräuning A, Liu J, Davis ME and Shao Y (2009) Temperature changes on the Tibetan Plateau during the past 600 years inferred from ice cores and tree rings. Global Planet. Change, 69, 71-78 (doi: 10.1016/j.gloplacha.2009.07.008)

Yang B, Kang X, Liu J, Bräuning A and Qin C (2010) Annual temperature history in Southwest Tibet during the last 400 years recorded by tree rings. Int. J. Climatol., 30, 962-971 (doi: 10.1002/joc.1956)

Yao T, Shi Y and Thompson LG (1997) High resolution records of paleoclimate since the Little Ice Age from the Tibetan Plateau. Quat. Int., 37, 19-23 (doi: 10.1016/1040-6182(96)00006-7)
Yao $\mathrm{T}$ and 8 others (2006) $\delta^{18} \mathrm{O}$ record and temperature change over the past 100 years in ice cores on the Tibetan Plateau. Sci. China, 49(1), 1-9 (doi: 10.1007/s11430-004-5096-2)

Yao T and 7 others (2007) Temperature variations over the past millennium on the Tibetan Plateau revealed by four ice cores. Ann. Glaciol., 46, 362-366 (doi: 10.3189/ 172756407782871305)

Yao T and 14 others (2012) Different glacier status with atmospheric circulations in Tibetan Plateau and surroundings. Nature Climate Change (doi: 10.1038/NCLMATE1580)

Yao T and 13 others (2013) A review of climatic controls on $\delta^{18} \mathrm{O}$ in precipitation over the Tibetan Plateau: observations and simulations. Rev. Geophys., 51, 1-24 (doi: 8755-1209/13/ 10.1002/rog.20023)

Ye Q, Kang S, Chen F and Wang J (2006) Monitoring glacier variations on Geladandong mountain, central Tibetan Plateau, from 1969 to 2002 using remote-sensing and GIS technologies. J. Glaciol., 52(179), 537-545 (doi: 10.3189/ 172756506781828359)

You Q and 6 others (2010) Climate warming and associated changes in atmospheric circulation in the eastern and central Tibetan Plateau from a homogenized dataset. Global Planet. Change, 72, 11-24 (doi: 10.1016/j.gloplacha.2010.04.003)

Yu R and Zhou T (2004) Impacts of winter-NAO on March cooling trends over subtropical Eurasia continent in the recent half century. Geophys. Res. Lett., 31, L12204 (doi: 10.1029/ 2004GL019814)

Zhang G, Li Z, Wang W and Wang W (2014) Rapid decrease of observed mass balance in the Urumqi Glacier No.1, Tianshan Mountains, central Asia. Quat. Int., 349, 135-141 (doi: 10.1016/j.quaint.2013.08.035)

Zhang Y, Kang S, Zhang Q, Cong Z and Zhang Y (2007) Snow ice records on Mt. Geladaindong in the central Tibetan Plateau. J. Glaciol. Geocryol., 29(5), 685-693 [in Chinese with English summary]

Zhao $\mathrm{H}$ and 6 others (2011) Deuterium excess record in a southern Tibetan ice core and its potential climatic implications. Climate Dyn., 38(9-10), 1791-1803 (doi: 10.1007/s00382-011-1161-7)

Zhu H, Xu P, Shao X and Luo H (2012) Little Ice Age glacier fluctuations reconstructed for the southeastern Tibetan Plateau using tree rings. Quat. Int., 283, 134-138 (doi: 10.1016/j. quaint.2012.04.011) 